\title{
Next generation sequencing and analysis of a conserved transcriptome of New Zealand's kiwi
}

\author{
Sankar Subramanian ${ }^{1,2}$, Leon Huynen ${ }^{1,2}$, Craig D Millar ${ }^{3}$, David M Lambert ${ }^{1,2^{*}}$
}

\begin{abstract}
Background: Kiwi is a highly distinctive, flightless and endangered ratite bird endemic to New Zealand. To understand the patterns of molecular evolution of the nuclear protein-coding genes in brown kiwi (Apteryx australis mantelli) and to determine the timescale of avian history we sequenced a transcriptome obtained from a kiwi embryo using next generation sequencing methods. We then assembled the conserved protein-coding regions using the chicken proteome as a scaffold.

Results: Using 1,543 conserved protein coding genes we estimated the neutral evolutionary divergence between the kiwi and chicken to be $\sim 45 \%$, which is approximately equal to the divergence computed for the humanmouse pair using the same set of genes. A large fraction of genes was found to be under high selective constraint, as most of the expressed genes appeared to be involved in developmental gene regulation. Our study suggests a significant relationship between gene expression levels and protein evolution. Using sequences from over 700 nuclear genes we estimated the divergence between the two basal avian groups, Palaeognathae and Neognathae to be 132 million years, which is consistent with previous studies using mitochondrial genes.

Conclusions: The results of this investigation revealed patterns of mutation and purifying selection in conserved protein coding regions in birds. Furthermore this study suggests a relatively cost-effective way of obtaining a glimpse into the fundamental molecular evolutionary attributes of a genome, particularly when no closely related genomic sequence is available.
\end{abstract}

\section{Background}

DNA sequencing technologies have enabled us to decipher molecular sequences of individual organisms. Conventional DNA sequencing methods relying on fluorescent dideoxy terminators and capillary separation revolutionized sequencing and allowed the first constructions of complete genomes of a number of species from simple prokaryotes to higher vertebrates $[1,2]$. However the costs involved in eukaryotic genomesequencing projects using these methods has been very high and thus such projects generally require the collaboration of several well-funded institutes. Furthermore the time required for sequencing and assembling such genomes can span several years. The advent of Next Generation DNA sequencing has reduced the time and expense of complete genome sequencing by orders of

\footnotetext{
* Correspondence: d.lambert@griffith.edu.au

'Griffith School of Environment and the School of Biomolecular and Physical Sciences, Griffith University, 170 Kessels Road, Nathan, Qld 4111 Australia Full list of author information is available at the end of the article
}

magnitude $[3,4]$. For example using next generation sequencing methods the complete genome of a human individual was completed in eight weeks by spending only a fraction of cost incurred using conventional BAC and shotgun-based cloning and sequencing methods [5].

The major limitation of a next generation sequencing approach is that the length of the sequence reads produced was until recently only 25-200 bases, as opposed to over a kilobase generated by conventional capillarybased sequencing methods. Although short sequence reads do not limit the amount of sequence data collected, this can hamper the assembly of the short sequence reads into large contigs. Therefore the availability of a genome of a closely related organism is generally required (to act as a scaffold) for the successful assembly of a new genome using the next generation sequencing method. For example, the assembly of the genomes of Neanderthal and Woolly Mammoth was possible only because of the availability, respectively, of complete human and African elephant genomes [6,7].
C Biomed Central

(c) 2010 Subramanian et al; licensee BioMed Central Ltd. This is an Open Access article distributed under the terms of the Creative Commons Attribution License (http://creativecommons.org/licenses/by/2.0), which permits unrestricted use, distribution, and reproduction in any medium, provided the original work is properly cited. 
Recently new algorithms have been developed to assemble genomes de novo without using a closely related scaffold genome [8]. However for precise genome assembly using this software, substantial sequence coverage is required. For example, using next generation sequencing and de novo assembly the complete genome of a Chinese panda was obtained at $50 \times$ (times) coverage [9]. Although the sequence required (150 gigabases) was generated in only one month, the cost amounted to several million US dollars. Therefore without the availability of a closely related organism, assembling complete genomes de novo would still be financially restrictive for most research laboratories. An alternative would be to use low-coverage next generation sequencing to sequence and assemble only the transcribed regions of a genome (transcriptome).

Large-scale comparative genomic studies of avian genomes started soon after the chicken genome became available [10]. These studies revealed mutational rate differences among chromosomes by comparative analyses of chicken and turkey genomes [11,12]. With the availability of the complete genome of the zebra finch [13] a number of studies have examined genome-wide patterns of molecular evolution and gene expression in avian genomes [14-17]. However all these studies were performed using only the Neognathae birds.

In the current study we have sequenced and assembled a number of conserved protein-coding regions of an early stage transcriptome of a Paleognathae bird, the North Island Brown kiwi (Apteryx australis mantelli). Kiwi are flightless birds endemic to New Zealand, and are of high conservation importance. The purpose of this study was to isolate conserved transcribed sequences of kiwi in order to understand firstly the patterns of mutation and selection amongst protein coding sequences and secondly to use these nuclear gene sequences to reanalyze the divergence time between Paleo- and Neognathae birds.

\section{Results and Discussion}

\section{Preliminary kiwi transcriptome analysis}

Initial cDNA made from kiwi embryo k11-15 was tested for coverage by amplification of the temporally and spatially restricted developmental genes $t b x 5$, cry 1 , pax 6 , $B M P 4$, ptx 1, hoxB1, hoxB8, and hoxD12. All genes were successfully amplified from the kiwi cDNA suggesting a comprehensive early stage kiwi transcriptome. As expected, comparison of the amplified kiwi gene sequences with those in GenBank consistently gave the chicken homologue as the closest match.

\section{Assembly of the conserved regions of Kiwi protein-coding genes}

To assemble over 75,000 FLX sequence reads we used the well-annotated chicken proteome. Kiwi sequences were used as a query to search over 22,000 chicken proteins using BLASTX. Significant hits were garnered and redundant kiwi reads were excluded. Garnered kiwi sequences were assembled into large contiguous segments. We used Blast2seq to align chicken proteins with translated assembled reads of kiwi. Finally we retained only the regions of the assembled reads where at least $90 \%$ of the amino acids aligned with their respective chicken orthologs. Although this resulted in a significant reduction in the number of kiwi genes retained, such an approach was required to minimize lineage specific duplicates. Furthermore we are confident that this approach will exclude most of the transcribed pseudogenes, which generally have a high rate of substitution. This stringent approach identified 1,543 kiwi genes. The locations of the chicken-orthologs of kiwi genes on the chicken chromosomes are shown in Figure 1. The average length of coding regions was $168 \mathrm{bp}$ (Figure 2). Our approach to assemble the transcriptome is somewhat similar to a previous method, SCARF [18]. However SCARF is suitable only if the reference scaffold genome is closely related to the target genome with a synonymous divergence of $<0.1$.

\section{Embryonic expression levels of kiwi genes}

Since the sequences generated in this study were from the mRNAs of a kiwi embryo, the copy numbers of the

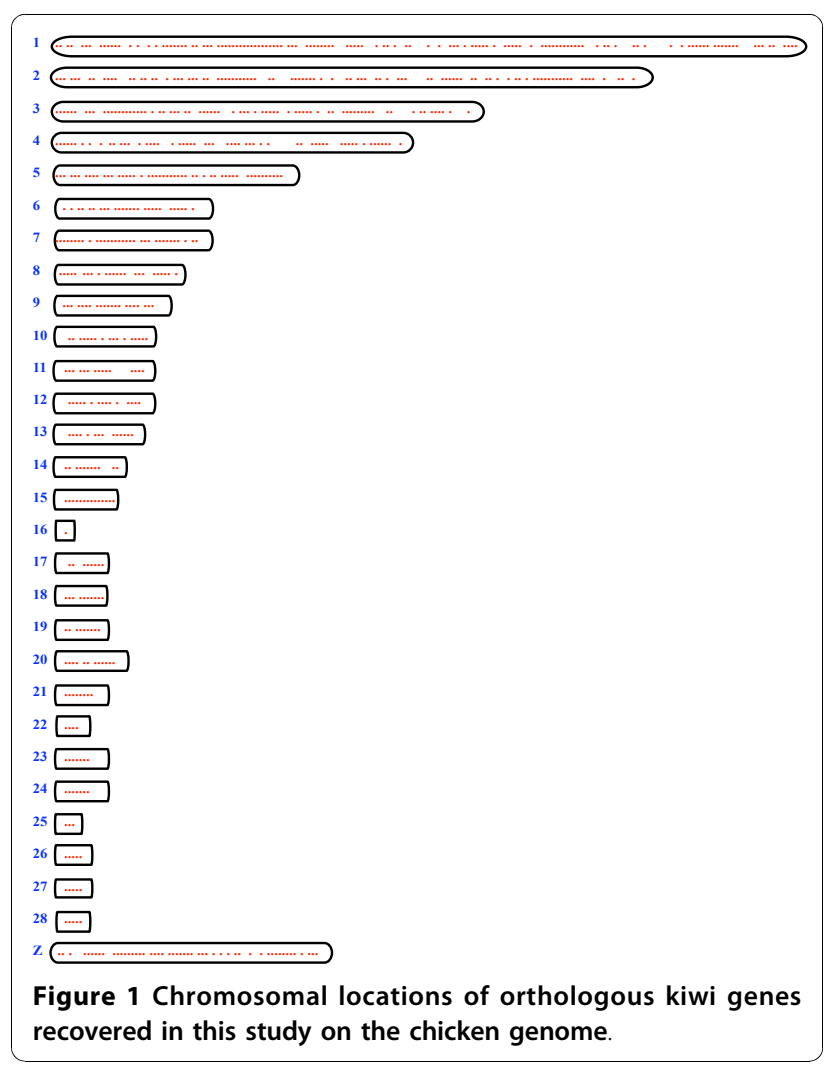




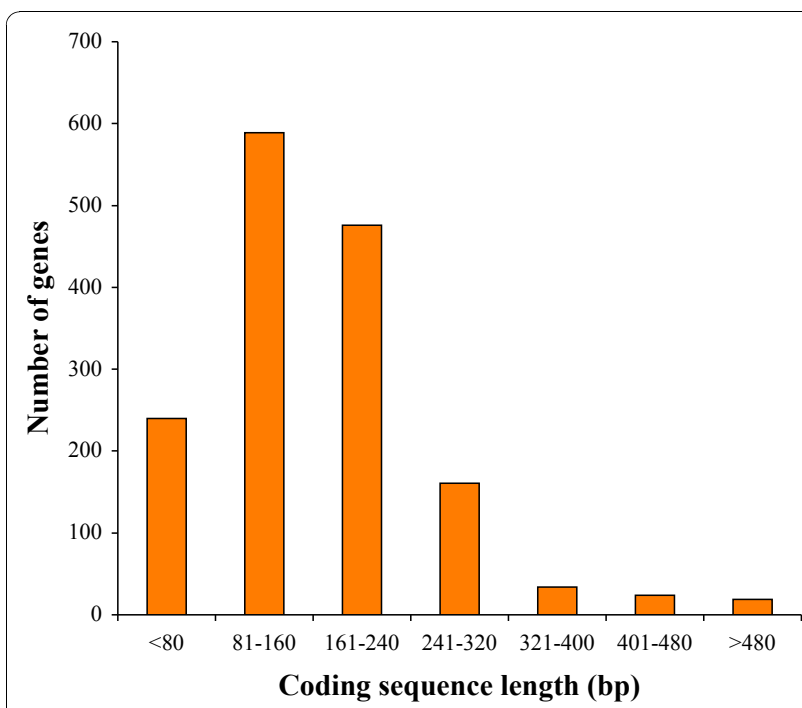

Figure 2 The distribution of the lengths of kiwi protein-coding regions sequenced and assembled in this study.

genes reflect their expression levels. We found two genes with very high (> 2000 copies) expression levels. While we identified (through the functional annotation of its chicken ortholog) the product of one of these genes as a neuropeptide the function of the other could not be determined. We grouped kiwi genes into three categories based on their levels of expression. Roughly $14 \%$ of the genes were highly expressed (> 5 copies) while $50 \%$ of the genes appeared to be present as single copies in kiwi embryo (Figure 3A). Conversely the small fraction of highly expressed genes constituted approximately $59 \%$ of the expressed mRNAs in the embryo, whereas only $13 \%$ of the mRNAs were from genes with low expression levels (Figure 3B). For this analysis we did not include the two genes with very high expression levels (mentioned above) to avoid bias due to these outliers. Gene annotations show that most of the highly expressed genes were those involved in protein synthesis such as ribosomal proteins, elongation factors, tRNA synthetases, as well as structural proteins such as collagen.

\section{Evolutionary divergence at neutral and constrained sites}

An important parameter used extensively in genome analyses is the rate of molecular evolution. To examine the rate of neutral evolution we compared the concatenated kiwi transcripts with those of chicken. A likelihood-based distance analysis showed that divergence at neutral synonymous sites was 0.465 substitutions per site. Conversely, divergence at nonsynonymous positions was only 0.071 substitutions per site; over an order of magnitude less than that of neutral divergence and suggests that high levels of purifying selection are

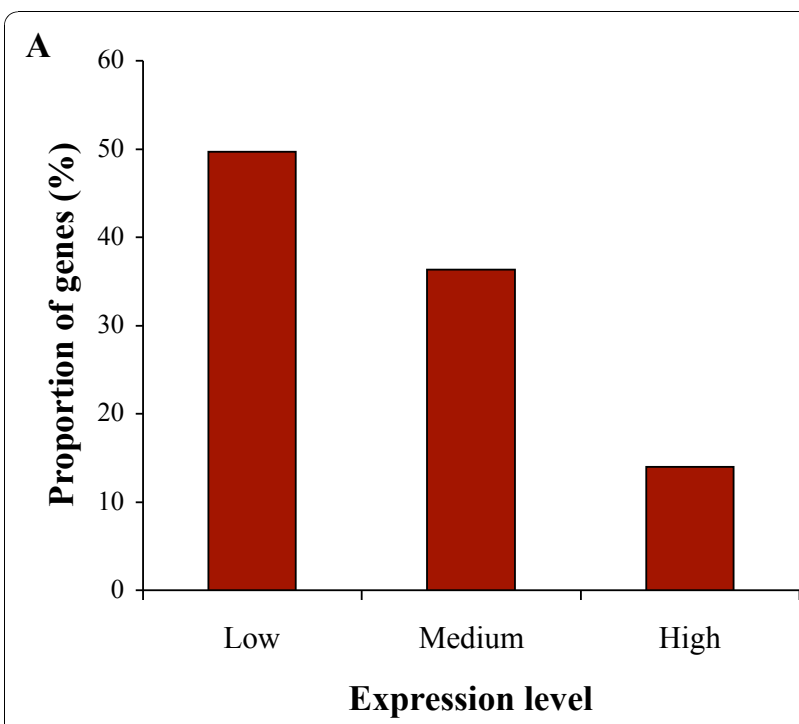

B

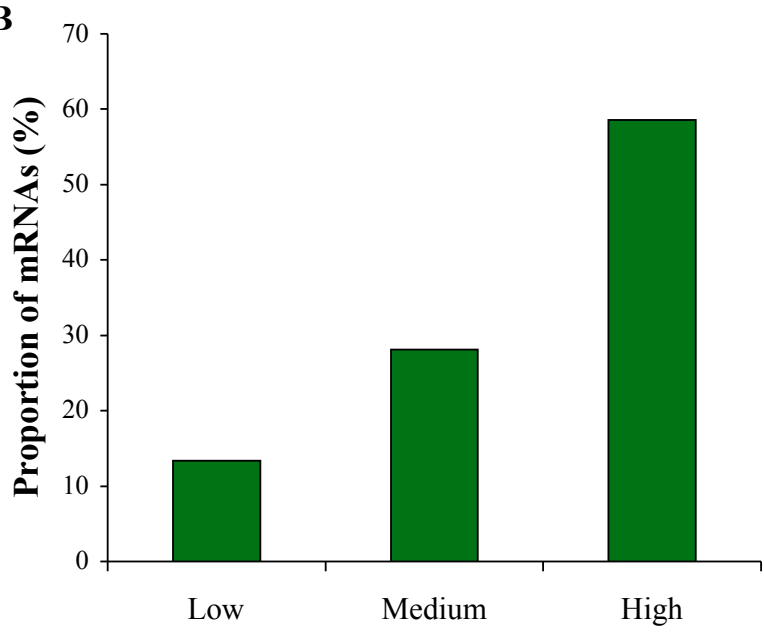

Expression Level

Figure 3 Kiwi transcript expression levels. A. Proportion of kiwi genes belonging to high (> 5 copies), medium (2-5 copies) and low (1 copy) expression levels based on the number of mRNA copies. B. Percentage of mRNAs belonging to different expression level categories.

acting on amino acid replacement sites. This is perhaps not surprising as the genes analyzed in this study are expressed early in embryonic development and therefore most are expected to be highly conserved. The average ratio of nonsynonymous- to synonymous divergences $(\mathrm{dN} / \mathrm{dS})$ was $0.15( \pm 0.002)$, which is comparable to that estimated using chicken-zebra finch sequences for the genes expressed in zebra finch embryo [16]. A previous study using zebra finch and emu (another palaeognathae bird) estimated the divergences at synonymous and nonsynonymous positions to be 0.47 and 0.04 respectively [19]. However we 
found a much higher divergence between zebra finch and kiwi at synonymous (0.53) and nonsynonymous (0.07) positions, which suggests that the rate of evolution in kiwi might be faster than that of emu.

The distribution of the $\mathrm{dN} / \mathrm{dS}$ ratio estimated for individual genes shows that over $60 \%$ of the genes were highly constrained $(\mathrm{dN} / \mathrm{dS}<0.1)$ (Figure 4$)$. On the other hand only $5 \%$ of the genes had a high $(>0.5) \mathrm{dN} / \mathrm{dS}$ ratio. Among these we found 25 genes that appear to be evolving under positive selection $(\mathrm{dN} / \mathrm{d} S>1.0)$. However the difference between the $\mathrm{dN}$ and $\mathrm{dS}$ estimates was not statistically different (higher) for any gene. This is primarily due to the high variance in the estimates, caused by the short sequence length of the partial genes used in this analysis and this adversely affects $\mathrm{dS}$ estimates over $\mathrm{dN}$ estimates, as synonymous sites are fewer than replacement sites. A previous study observed a higher rate of evolution in the zebra finch lineage compared to chicken using anole lizard as an outgroup [17]. We examined this using kiwi as an outgroup and found an approximately $50 \%$ higher rate of evolution in the zebra finch lineage compared to chicken at synonymous (49\%) as well as at nonsynonymous (57\%) positions.

To compare sequence divergence between the birds and mammals we obtained the orthologous human and mouse genes and used the alignment that contained only the aligned regions from kiwi, chicken, human and mouse. Therefore we could examine the rates and patterns of evolution in the same genes and regions from mammals and birds. This analysis using 616 genes

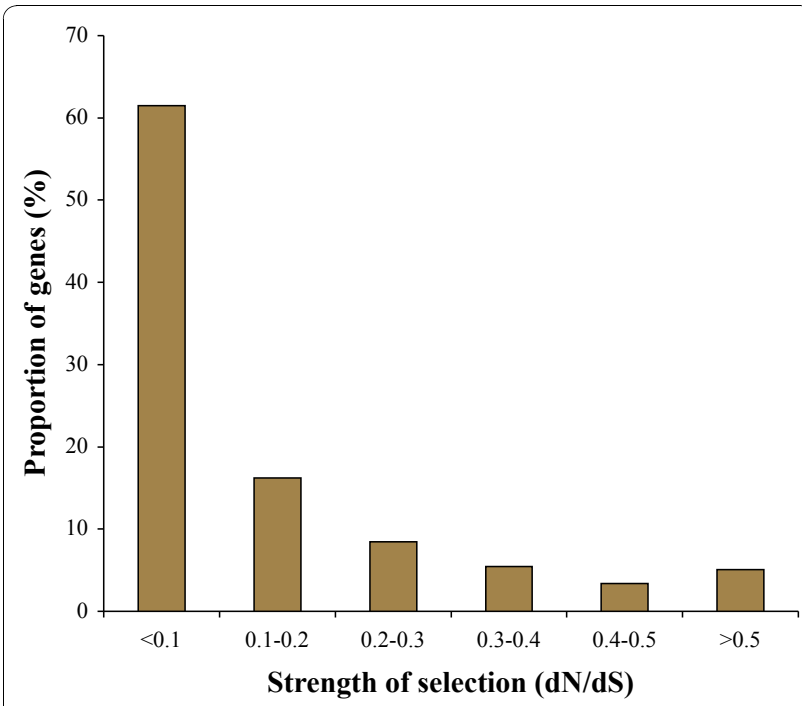

Figure 4 Distribution of kiwi genes under varying levels of selective constraint. The strength of selection was determined by the ratio of divergence at nonsynoymous positions ( $d N)$ to the divergence at synonymous sites (dS). The divergence (substitutions per site) was estimated for 1,543 kiwi-chicken orthologus gene pairs using PAML [31]. showed that the divergence at synonymous sites between chicken and kiwi was almost identical to that between human and mouse $(0.453 \mathrm{Vs} 0.465, P=0.13)$. Therefore the mutation rates of mammals and birds could be similar if the divergence times between human-mouse and chicken-kiwi splits are comparable. Molecular data based studies estimates suggest a $\sim 115$ My split for primates-rodents divergence [20] and a $\sim 130$ My split for paleo-neognathae birds [21,22]. Furthermore fossil-based estimates also suggest a similar divergence time for the primates-rodents split (62 My $100 \mathrm{My}$ ) and for palaeognathae-neognathae split [23]. However the nonsynonymous divergence for the chicken-kiwi pair was significantly higher than that estimated for the human-mouse comparison $(0.055 \mathrm{Vs}$ $0.028, P<0.0001)$. This suggests that despite the similarity in neutral substitution rates between mammals and birds, the magnitude of purifying selection appears to be much higher in the former than the latter. Although the low coverage of our sequence data might include some sequencing errors $(<0.005$ per site) it will not significantly affect our results as the comparative analyses presented here involve only distantly related species.

Previous studies showed a low nonsynonymous divergence in highly expressed genes, owing to a higher selection constraint on these genes [24,25]. We examined this for the kiwi-chicken species pair and found that this also holds true for these avian species. We found that the highly expressed genes are generally highly constrained and conversely the rate of evolution at nonsynonymous sites of the genes with low expression levels showed a large variation [see also [25]]. Therefore a simple correlation analysis does not capture the actual relationship between expression level and the rate of nonsynonymous site evolution. Hence, we estimated the divergences at synonymous and nonsynonymous sites of genes with high, medium and low expression levels by concatenating the genes in each group. The nonsynonymous divergence of genes with low expression levels was found to be $50 \%$ higher than that of the genes with a high expression level (0.082 vs $0.054)$ and this difference was statistically significant $(P<0.0001)$ using a Z-test (Figure 5A, red). However the divergence at synonymous sites of lowly expressed genes was not significantly different to that of the highly expressed genes $(0.464$ vs $0.458 P=0.58)$ (Figure $5 \mathrm{~B}$, red).

The expression levels determined for kiwi genes might be influenced by the level of coverage of individual genes. Therefore we obtained the expression levels for the orthologous chicken genes using an embryonic chicken library (with 22000 ESTs) [26]. Only those genes that had a high expression level (> 5 copies of 


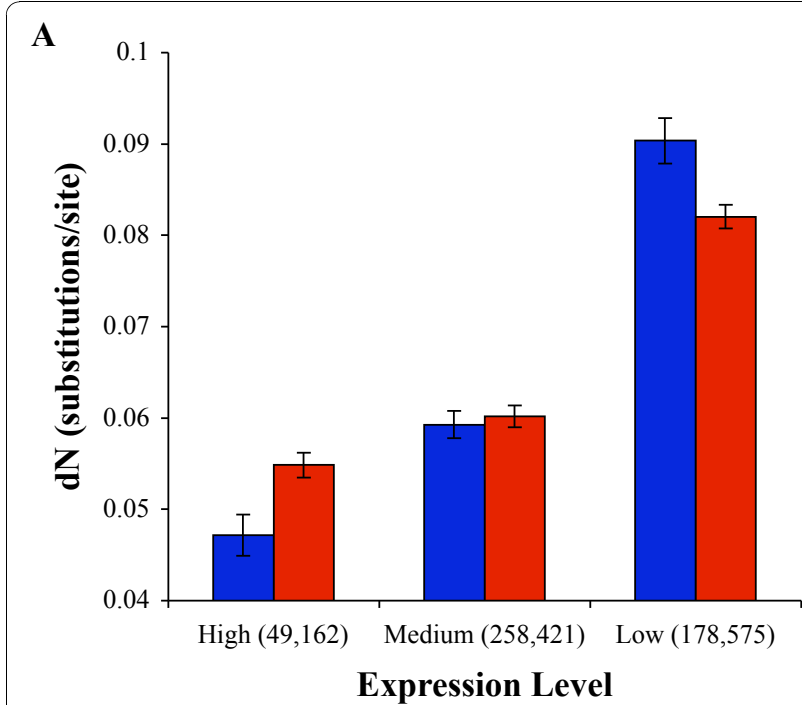

B

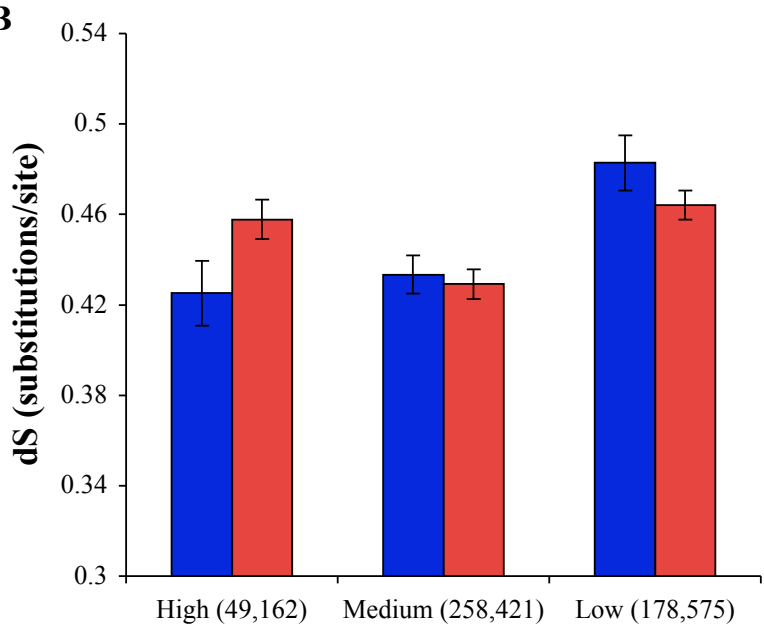

Expression Levels

Figure $\mathbf{5}$ Rate of evolution of conserved kiwi coding sequences and gene expression levels. The three categories of expression level are based on kiwi as well as chicken embryonic expression data (blue) or based on kiwi embryonic expression data only (red). A. Mean divergence (substitutions per site) at nonsynonymous sites in kiwi genes from different expression levels. B. Average

divergence at synonymous positions. Error bars show the standard error of the mean estimates. The number of genes used are given in parentheses.

mRNA) in kiwi as well as in chicken embryos were designated as highly expressed genes. Similarly we determined the genes with medium and low expression levels. Although this reduced the number of genes in our analysis, this stringent approach also produced similar relationships between expression levels and the divergences (Figure 5A and 5B, blue). This analysis showed an almost two fold higher nonsynonymous divergence for lowly expressed genes than that of the genes with high expression level $(0.090 \mathrm{Vs} 0.047, P<$ 0.0001 ). The difference in the synonymous divergences between the genes with low and high expression levels was only $14 \%$ but was statistically significant $(0.483 \mathrm{Vs}$ $0.425, P=0.002)$. This result suggests very weak selection in synonymous sites of conserved genes of birds.

\section{Functional categories of proteins expressed in the kiwi embryo}

To determine the functions associated with the kiwi proteins we obtained the functional annotations of their orthologous chicken counterparts from the Biomart resource ENSEMBL http://www.ensembl.org. Our search using the gene ontology classification of chicken genes resulted in the identification of gene function for $\sim 500$ genes. We found that the majority of the kiwi genes (41\%) code for DNA/RNA- or protein-binding proteins (Figure 6A). This is not surprising as these proteins are largely involved in the control of transcription; an important regulatory activity expected in developing embryos. Furthermore proteins that regulate translation were found to constitute roughly $8 \%$. Other major fractions of proteins detected were those that perform housekeeping functions such as catalysis (enzymes) $(22 \%)$ and transport (17\%).

We also determined the types metabolic pathways with which the kiwi genes are involved. This was done using information from the KEGG pathway database http://www.genome.jp/kegg/pathway.html for the chicken genes, which were then assigned to the corresponding orthologous kiwi genes. Figure $6 \mathrm{~B}$ shows that roughly a quarter of kiwi genes were involved in genetic information processing pathways, which includes DNA replication and transcription. Approximately $27 \%$ and $21 \%$ of the genes were found to be associated with cellular and metabolic processes respectively. The remaining $14 \%$ of genes were shown to be involved in immunity and the endocrine system and $11 \%$ of the genes were associated with environmental processing including transport and signal transduction.

\section{Divergence times between Paleo- and Neognathae}

We attempted to determine the divergence time between paleo- and neognathae birds as well as that between Galloanseriformes and the remaining neognathae birds. For this purpose we compared the genomes of neognathae birds (chicken and zebra finch), a reptile (anole lizard) and used a mammal (human) as an outgroup. The orthologous sequences of these genomes were obtained using reciprocal BLAST. This resulted in an orthologous dataset of 702 genes and included only those protein-coding sequences that align with the kiwi transcripts. The nucleotide sequences of all genes were concatenated and the branch lengths were estimated 


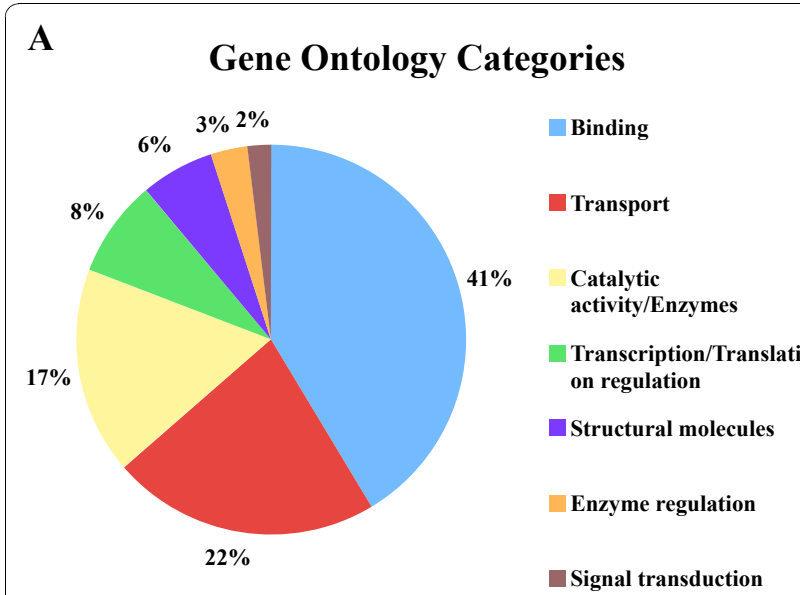

\section{B KEGG Pathways Categories}

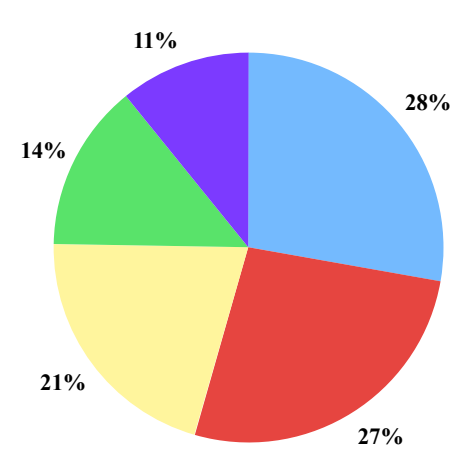

Genetic Information
Processing
Cellular processes
Metabolism
Organismal Systems
Environmental
Information Processing

Figure 6 Functional categories of kiwi genes. A. Functional classifications are as described in the Gene Ontology Consortium http://www.geneontology.org. B. Classification of genes are based on their involvement in various pathways as categorized by the KEGG pathways database http://www.genome.jp/kegg/pathway. $\mathrm{html}$. The functions and pathway involvement of kiwi genes were deduced from their chicken counterparts for which gene ontology functions or KEGG pathway information were available.

using BASEML under a general time reversible model of sequence evolution using the tree topology shown in Figure 7. First we conducted a simple direct estimation of the divergence times using pair-wise ML distances and a calibration time of 255 My (million years) between reptiles and birds. The latter was obtained from fossil studies [27]. This yielded a time of $130 \mathrm{My}$ for the paleo- and neognathae split (using a kiwi and chicken/ zebra finch pair) and $110 \mathrm{My}$ for Galloanseriformes and other neognathae birds (chicken and zebra finch pair). Similar divergence times were obtained using a fossil calibration time of $310 \mathrm{My}$ for the bird-mammal divergence [28]. We also performed a more rigorous Bayesian approach using the program Mutidivetime [29]. The divergence time estimates were $132 \mathrm{My}$ (80 My - 170

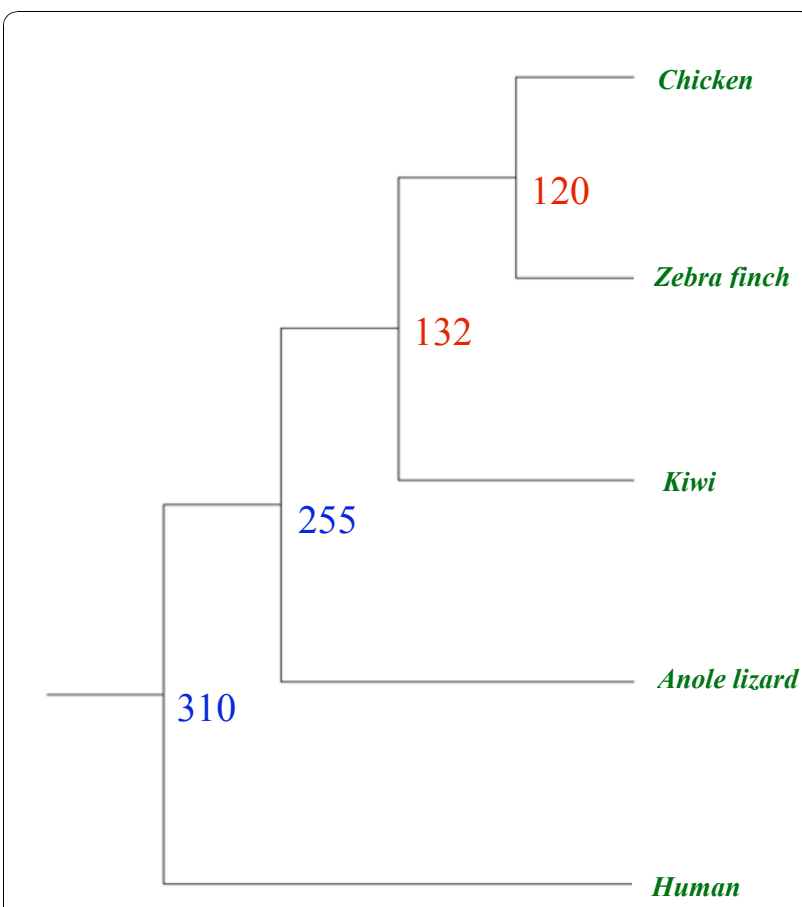

Figure 7 Divergence times estimated using the software Multidivtime [29]. Nuclear genes (702) from kiwi and other completed genomes of chicken, zebra finch, anole lizard, and human were used in this estimation. To calibrate the evolutionary divergences a fossil-based divergence time of 255 My [27] was used for the reptile-bird split.

My) for the paleo- and neognathae birds and $120 \mathrm{My}$ (70 My - $150 \mathrm{My)}$ for chicken-zebra finch pair, which are similar to those obtained using the direct method (Figure 7). Furthermore, we estimated the divergence times using BEAST without forcing any phylogenetic relationship among the species. Using the three birds and the anole lizard sequences we obtained the divergence times estimate by calibrating the molecular clock using the avian-reptile fossil based divergence time of $255 \mathrm{My}$. This analysis produced an estimate of $157 \mathrm{My}$ (143 My -173 My), which is slightly higher than that obtained using the previous method. However, the confidence or HPD (Highest Posterior Density) intervals obtained from BEAST were within those obtained using Multidivtime. The divergence time computed by BEAST for the chicken-zebra finch split was $122 \mathrm{My}$ (110 My$134 \mathrm{My}$ ), which is similar to that obtained using Multidivtime. Furthermore, we estimated the divergence times directly using the neutral synonymous evolutionary rates estimated by a previous study. A previous study using over 8,000 protein coding genes from chicken, zebra finch and anole lizard estimated the rate of neutral synonymous site evolution to be $1.23 \times 10^{-9}$ to $2.21 \times 10^{-9}$ [17]. Using an average rate of $1.7 \times 10^{-9}$ 
and a synonymous divergence of 0.452 we estimated the divergence time between kiwi (Paleognathae) and chicken (Neognathae) to be $133 \mathrm{My}$. Similarly using this rate and the neutral distance of 0.417 , the divergence time for chicken-zebra finch pair was computed to be $123 \mathrm{My}$. Clearly the divergence times estimated in this study using the three different methods are largely similar. Furthermore these time estimates are comparable to those obtained using complete avian mitochondrial genomes $[21,22]$.

\section{Conclusions}

Using next generation sequencing technology our study provides some important insights into the conserved kiwi transcriptome. The neutral divergence at conserved protein coding genes of kiwi and chicken was found to be comparable to the synonymous divergence between human and mouse. However the divergence at amino acid replacement positions of these birds is much higher than the mammals suggesting a greater selective pressure in the latter. Similar to the observations from the studies on mammals, a negative relationship between gene expression levels and rate of protein evolution was found in birds. This study provides divergence time estimates between paleognathae and neognathae birds based on $>700$ nuclear genes.

The conserved kiwi transcriptome data reported here are useful for further specific studies on kiwi genetics and will assist future complete kiwi genome sequencing efforts, specifically in aiding genome assembly and determining gene structure. Importantly, our study provides a cost effective way to perform preliminary genome-based analyses and allows examination of some fundamental developmental and evolutionary processes of a species in the absence of a closely related genome.

\section{Methods}

\section{Kiwi embryo}

A young male kiwi embryo (sample k11-15) was kindly provided by Suzanne Bassett from the University of Otago, New Zealand. The embryo was void of any discernable structures and resembled an asymmetric gelatinous mass of approximately $15 \mathrm{~mm}$ in diameter. The small size and lack of obvious features suggested the embryo was at a very early stage of tissue building.

\section{RNA extraction and preliminary transcriptome characterization}

Several $2 \mathrm{~mm}^{2}$ slices were removed from equispaced regions around the kiwi embryo, combined, and total RNA was extracted using Trizol ${ }^{\text {tw }}$, then precipitated with ethanol and resuspended in $50 \mu \mathrm{l}$ of Milli-Q water. Five microlitres of total RNA was reverse transcribed in a 50 $\mu \mathrm{l}$ volume containing $50 \mathrm{mM}$ Tris $-\mathrm{Cl} \mathrm{pH} 8.8,75 \mathrm{mM}$
$\mathrm{KCl}, 5 \mathrm{mM} \mathrm{MgCl} 2,10 \mathrm{mM}$ DTT, $100 \mathrm{ng}$ oligodT $_{18}$ $0.5 \mathrm{mM}$ of each dNTP, and $200 \mathrm{U}$ of Moloney Murine Leukemia Virus reverse transcriptase. The mix was incubated at $42^{\circ} \mathrm{C}$ for $1 \mathrm{hr}$ and extracted with phenol:chloroform. The complementary DNA (cDNA) was precipitated with ammonium acetate and ethanol, washed with $80 \%$ ethanol, and the resulting pellet was resuspended in $40 \mathrm{ul}$ of $\mathrm{H}_{2} \mathrm{O}$. Complementary DNA was amplified in $10 \mu \mathrm{l}$ reactions containing $50 \mathrm{mM}$ Tris- $\mathrm{Cl}$ $\mathrm{pH} 8.8,20 \mathrm{mM}\left(\mathrm{NH}_{4}\right)_{2} \mathrm{SO}_{4}, 2.5 \mathrm{mM} \mathrm{MgCl} 2,1 \mathrm{mg} / \mathrm{ml}$ BSA, $200 \mathrm{uM}$ of each dNTP, $40 \mathrm{ng}$ of each primer, and $\sim 0.3 \mathrm{U}$ of platinum Taq (Invitrogen). The reaction mix was overlaid with mineral oil and subjected to amplification in a Hybaid OmniGene thermal cycler using the following parameters: $94^{\circ} \mathrm{C}$ for $2 \mathrm{~min}(\times 1), 94^{\circ} \mathrm{C}$ for $20 \mathrm{sec}, 54^{\circ} \mathrm{C}$ for $20 \mathrm{sec}, 72^{\circ} \mathrm{C}$ for $20 \mathrm{sec}(\times 15)$, and then $94^{\circ} \mathrm{C}$ for $20 \mathrm{sec}, 50^{\circ} \mathrm{C}$ for $20 \mathrm{sec}$, and $72^{\circ} \mathrm{C}$ for $20 \mathrm{sec}(x$ 30). Amplified DNAs were detected by agarose gel electrophoresis in Tris-borate-EDTA buffer (TBE), stained with $50 \mathrm{ng} / \mathrm{ml}$ ethidium bromide in TBE, and then visualized over UV light. Positive amplifications were purified by centrifugation through $\sim 40 \mu$ of dry Sephacryl $^{{ }^{m} \mathrm{~S}} \mathrm{~S} 300 \mathrm{HR}$ and then sequenced at the Allan Wilson Centre Genome Sequencing Service using Applied Biosystems (ABI) BigDye Terminator v3.1 chemistry and an ABI3730 Genetic Analyzer. The primers used were designed to a selection of developmental and regulatory genes. In all cases the primers spanned an intron of at least $500 \mathrm{bp}$. The primers pairs used and genes targeted were: $t b x 5 \_2$ Fii- agtccaaagagctgcaggctga and $t b x 5 \_4 \mathrm{R}$ catccgctggtacaatatccat; cry1F-tctgatgaccatgatgaga and $c r y 1 \mathrm{R}$-ctgtgtagaaaaattcacgcca; $p x 6 \mathrm{~F}$-accatgcagaac agtcacag and $p x 6 \mathrm{R}$-acaacttcgggagtcgctact; $B M P 4 \mathrm{~F}$-tgct gcagatgtttgggct and BMP4R-ccgacgagatcacctcgtt; $p t x 1 \mathrm{~F}$ gccactttccagcggaaccg and $p t x 1 \mathrm{R}$-gctcatggagttgaagaaggt; $h \times B 1 \mathrm{~F}$-cggaccttcgattggatgaa and $h \times B 1 \mathrm{R}$-tcttgacttgggt ttcgttgagct; $h \times B 8 \mathrm{~F}$-caaatccaggagttctaccac and $h \times B 8 \mathrm{R}$ gtctggtagcggctgtaggt; $h x D 12 \mathrm{~F}$-tcaacttgaacctgacagt and $h x D 12 \mathrm{R}$-cgtcggttctgaaaccaaatttt.

\section{Transcriptome preparation and amplification for FLX sequencing}

Approximately $10 \mu \mathrm{g}$ of total RNA was reverse transcribed using oligod $\mathrm{T}_{18}$ as outlined above, and second strand cDNA was synthesized in the same tube by adding $40 \mu \mathrm{l}$ of $5 \times$ second strand buffer $(100 \mathrm{mM}$ Tris-Cl $\mathrm{pH} 7.0,25 \mathrm{mM} \mathrm{MgCl}_{2}, 450 \mathrm{mM} \mathrm{KCl}, 50 \mathrm{mM}\left(\mathrm{NH}_{4}\right)$ $\left.{ }_{2} \mathrm{SO}_{4}\right), 4 \mu \mathrm{l}$ of a $10 \mathrm{mM}$ solution of each dNTP, $7 \mathrm{ul}$ of $100 \mathrm{mM}$ DTT, $20 \mathrm{U}$ of E. coli DNA polymerase I, and water to $200 \mathrm{ul}$. The mix was incubated at room temp for $2 \mathrm{hrs}$, before the addition of $5 \mathrm{U}$ of T4 DNA polymerase I to blunt the dsDNA ends, and the dsDNA was purified by phenol:chloroform extraction and ethanol precipitation. The dsDNA pellet was resuspended in 
$10 \mathrm{ul}$ of $1 \times$ Promega ligase buffer and then ligated together overnight at $4^{\circ} \mathrm{C}$ with $3 \mathrm{U}$ of T4 DNA ligase. The ligated DNAs were purified and precipitated as described and resuspended in $10 \mu \mathrm{l}$ of water. One microlitre of the DNA was then amplified using Templify (Amersham) as instructed by the manufacturer, and a sample of the amplified DNA was checked by gel electrophoresis. Approximately $2 \mu \mathrm{g}$ of the amplified DNA was purified and sent to the University of Otago High-ThroughputDNA Sequencing Unit for megasequencing by FLX.

The amplified DNA was fragmented by nebulization. Sequencing adaptors were then ligated to the ends of these fragments and fragments that contained both adaptors were selected using biotin/streptavidin Library Immobilization Beads (Roche). The kiwi transcriptome library was not titrated. Instead an emPCR loading density of 1.5 copies per beads was chosen. Following this, the kiwi transcriptome library was annealed to enough DNA capture beads for 16 emulsions reactions of an emPCR I shotgun sequencing kit (Roche).

\section{Assembly of FLX sequence reads}

The amplified kiwi cDNA library was prepared and sequenced using 454 FLX sequencing chemistry, which generated 75,632 sequence reads with an average length of $171 \mathrm{bp}$. These reads were used as queries to search a database of 22,000 chicken proteins downloaded from GenBank. We used BLASTX to translate the coding sequences into all six reading frames. Significant threshold levels were based on query protein length, as described before [30]. Homopolymer tracts and adaptors were removed using perl scripts as well as by manual examination. The number of kiwi reads that had significant hits with the chicken proteome were found to be 23,417 (31\%). If there were more than two overlapping fragments the most frequent base was used to determine the consensus. These sequences were assembled using the criteria of a 20 bp identical overlap. Using blast2seq, chicken proteins and the translated segments were aligned and assembled. We used a stringent approach and extracted only the regions of kiwi coding sequences that had at least $90 \%$ identity to those of chicken. This conservative approach resulted in identification of 1,543 kiwi protein-coding genes with an average aligned (with chicken) length of $168 \mathrm{bp}$. This alignment did not show any bias in the genic location of the kiwi reads, as roughly $49 \%$ of the reads are from the 3' terminus of the genes and $51 \%$ are from the 5 ' terminus. Redundant (identical or subsets of) sequences were excluded from further analysis.

\section{Evolutionary rate estimation}

The rate of evolution was estimated using conserved kiwi-chicken sequences. Sequence alignments from all
1,543 genes were concatenated and the divergences at synonymous and nonsynonymous sites were estimated using the pair-wise option of the CODEML program [31]. This approach was also followed for groups of genes such as highly expressed genes. Furthermore pair-wise likelihood distances at synonymous and nonsynonymous sites were also estimated for individual genes. Since the lengths of the sequences recovered were short $(\sim 168 \mathrm{bp})$ the dS estimates for individual genes are subjected to higher stochastic errors than the $\mathrm{dN}$ estimates, which might result in overestimation of the $\mathrm{dN} / \mathrm{dS}$ ratios due to very small $\mathrm{dS}$ values. However we found only 10 genes with a very low $\mathrm{dS}$ $(<0.01)$ and therefore the genic $\mathrm{dN} / \mathrm{dS}$ ratios obtained for most of the genes were not affected by this overestimation.

\section{Estimation of divergence times}

Using a reciprocal BLAST hit approach [32] orthologous genes from three other vertebrates zebra finch, anole lizard, and human were also obtained. Protein sequences of five genomes (including chicken and kiwi) were aligned using CLUSTALW [33] and only those regions that aligned with the partial kiwi proteins were extracted. cDNA sequences of all these genomes were aligned using the protein alignments as a guide. The resultant 702 genes from five genomes were concatenated. Since the phylogenetic relationship between these five species is well known, the tree topology (as in Figure 7) was used to obtain the branch lengths using the program BASEML from PAML [31]. For this analysis a GTR+gamma (five categories) model was used.

To estimate divergence times we followed a Bayesian based approach implemented in the software Multidivtime $[29,34]$. The molecular clock was calibrated using the well documented fossil-based estimate of $255 \mathrm{My}$ (252 My - $257 \mathrm{My}$ ) for the reptile-avian split [27] and the human sequence was used as an outgroup. The lower and upper constraints used in the program were $230 \mathrm{My}$ and $280 \mathrm{My}$. We used $255 \mathrm{My}$ as the expected time between the (ingroup) root to the tip (rttime). The prior rate was calculated as the ratio of the median of the branch lengths from root-to-tip and the time elapsed as per the suggestion given in the documentation (Thorne and Kishino 2002). The prior standard deviation was kept as $50 \mathrm{My}$. Other priors used were as outlined in the Multidivtime documentation. Furthermore we used BEAST [35] to estimate the divergence times without constraining any phylogenic relationship among the species. For this purpose we used three birds and the lizard protein coding sequences. We used the Tamura Nei +Gamma model for sequence evolution and the reptile-bird fossil based divergence time to calibrate the molecular clock. 


\section{Acknowledgements}

We are grateful to the Massey University Foundation for financial support, the Massey University Development Fund and Griffith University for financial support. This research would never have been initiated, much less completed, without the support of Mike Freeman and the Massey University Foundation. We are also grateful to Dr Jo Stanton from Otago University for her assistance with Next Generation DNA Sequencing and to Suzanne Bassett for the supply of kiwi embryo material. The sequence read data has been submitted to Short Read Archive (Acc. no: SRA023683.2).

\section{Author details \\ 'Griffith School of Environment and the School of Biomolecular and Physical Sciences, Griffith University, 170 Kessels Road, Nathan, Qld 4111 Australia. ${ }^{2}$ Allan Wilson Centre for Molecular Ecology and Evolution, Institute of Molecular BioSciences, Massey University, Auckland, New Zealand. ${ }^{3}$ Allan Wilson Centre for Molecular Ecology and Evolution, School of Biological Sciences, University of Auckland, Private Bag 92019, Auckland, New Zealand.}

\section{Authors' contributions}

DML and CDM conceived the study. LH conducted laboratory experiments. SS performed data analysis and wrote the paper. DML, LH and CDM edited the paper. All authors read and approved the manuscript.

\section{Received: 13 July 2010 Accepted: 15 December 2010}

Published: 15 December 2010

\section{References}

1. Fleischmann RD, Adams MD, White O, Clayton RA, Kirkness EF, Kerlavage AR, Bult CJ, Tomb JF, Dougherty BA, Merrick JM, Mckenney K, Sutton G, Fitzhugh W, Fields C, Gocayne JD, Scott J, Shirley R, Liu LI, Glodek A, Kelley JM, Weidman JF, Phillips CA, Spriggs T, Hedblom E, Cotton MD, Utterback TR, Hanna MC, Nguyen DT, Saudek DM, Brandon RC, Fine LD, Fritchman JL, Fuhrmann JL, Geoghagen NSM, Gnehm CL, Mcdonald LA, Small KV, Fraser CM, Smith HO, Venter JC: Whole-Genome Random Sequencing and Assembly of Haemophilus-Influenzae Rd. Science 1995, 269:496-512.

2. Lander ES, Linton LM, Birren B, Nusbaum C, Zody MC, Baldwin J, Devon K, Dewar K, Doyle M, FitzHugh W, Funke R, Gage D, Harris K, Heaford A, Howland J, Kann L, Lehoczky J, LeVine R, McEwan P, McKernan K, Meldrim J, Mesirov JP, Miranda C, Morris W, Naylor J, Raymond C, Rosetti M, Santos R, Sheridan A, Sougnez C, Stange-Thomann N, Stojanovic N, Subramanian A, Wyman D, Rogers J, Sulston J, Ainscough R, Beck S, Bentley D, Burton J, Clee C, Carter N, Coulson A, Deadman R, Deloukas P, Dunham A, Dunham I, Durbin R, French L, Grafham D, Gregory S, Hubbard T, Humphray S, Hunt A, Jones M, Lloyd C, McMurray A, Matthews L, Mercer S, Milne S, Mullikin JC, Mungall A, Plumb R, Ross M, Shownkeen R, Sims S, Waterston RH, Wilson RK, Hillier LW, McPherson JD, Marra MA, Mardis ER, Fulton LA, Chinwalla AT, Pepin KH, Gish WR, Chissoe SL, Wendl MC, Delehaunty KD, Miner TL, Delehaunty A, Kramer JB, Cook LL, Fulton RS, Johnson DL, Minx PJ, Clifton SW, Hawkins T, Branscomb E, Predki P, Richardson P, Wenning S, Slezak T, Doggett N, Cheng JF, Olsen A, Lucas S, Elkin C, Uberbacher E, Frazier M, Gibbs RA, Muzny DM, Scherer SE, Bouck JB, Sodergren EJ, Worley KC, Rives CM, Gorrell JH, Metzker ML, Naylor SL, Kucherlapati RS, Nelson DL, Weinstock GM, Sakaki Y, Fujiyama A, Hattori M, Yada T, Toyoda A, Itoh T, Kawagoe C, Watanabe H, Totoki Y, Taylor T, Weissenbach J, Heilig R, Saurin W, Artiguenave F, Brottier P, Bruls T, Pelletier E, Robert C, Wincker P, Rosenthal A, Platzer M, Nyakatura G, Taudien S, Rump A, Yang HM, Yu J, Wang J, Huang GY, Gu J, Hood L, Rowen L, Madan A, Qin SZ, Davis RW, Federspiel NA, Abola AP, Proctor MJ, Myers RM, Schmutz J, Dickson M, Grimwood J, Cox DR, Olson MV, Kaul R, Raymond C, Shimizu N, Kawasaki K, Minoshima S, Evans GA, Athanasiou M, Schultz R, Roe BA, Chen F, Pan HQ, Ramser J, Lehrach H, Reinhardt R, McCombie WR, de la Bastide M, Dedhia N, Blocker H, Hornischer K, Nordsiek G, Agarwala R, Aravind L, Bailey JA, Bateman A, Batzoglou S, Birney E, Bork P, Brown DG, Burge CB, Cerutti L, Chen HC, Church D, Clamp M, Copley RR, Doerks T, Eddy SR, Eichler EE, Furey TS, Galagan J, Gilbert JGR, Harmon C, Hayashizaki Y, Haussler D, Hermjakob H, Hokamp K, Jang WH, Johnson LS, Jones TA, Kasif S, Kaspryzk A, Kennedy S, Kent WJ, Kitts P, Koonin EV, Korf I, Kulp D, Lancet D, Lowe TM, McLysaght A, Mikkelsen T, Moran JV, Mulder N, Pollara VJ, Ponting CP, Schuler G, Schultz JR, Slater G, Smit AFA, Stupka E,
Szustakowki J, Thierry-Mieg D, Thierry-Mieg J, Wagner L, Wallis J, Wheeler R, Williams A, Wolf YI, Wolfe KH, Yang SP, Yeh RF, Collins F, Guyer MS, Peterson J, Felsenfeld A, Wetterstrand KA, Patrinos A, Morgan MJ, Conso IHGS: Initial sequencing and analysis of the human genome. Nature 2001, 409:860-921.

3. Mardis ER: Next-generation DNA sequencing methods. Annu Rev Genomics Hum Genet 2008, 9:387-402.

4. Shendure J, Ji HL: Next-generation DNA sequencing. Nat Biotechnol 2008, 26:1135-1145.

5. Bentley DR, Balasubramanian S, Swerdlow HP, Smith GP, Milton J, Brown CG, Hall KP, Evers DJ, Barnes CL, Bignell HR, Boutell JM, Bryant J, Carter RJ, Cheetham RK, Cox AJ, Ellis DJ, Flatbush MR, Gormley NA, Humphray SJ, Irving L, Karbelashvili MS, Kirk SM, Li H, Liu XH, Maisinger KS, Murray $L$, Obradovic B, Ost T, Parkinson ML, Pratt MR, Rasolonjatovo IMJ, Reed MT, Rigatti R, Rodighiero C, Ross MT, Sabot A, Sankar SV, Scally A, Schroth GP, Smith ME, Smith VP, Spiridou A, Torrance PE, Tzonev SS, Vermaas EH, Walter K, Wu XL, Zhang L, Alam MD, Anastasi C, Aniebo IC, Bailey DMD, Bancarz IR, Banerjee S, Barbour SG, Baybayan PA, Benoit VA, Benson KF, Bevis C, Black PJ, Boodhun A, Brennan JS, Bridgham JA, Brown RC, Brown AA, Buermann DH, Bundu AA, Burrows JC, Carter NP, Castillo N, Catenazzi MCE, Chang S, Cooley RN, Crake NR, Dada OO, Diakoumakos KD, Dominguez-Fernandez B, Earnshaw DJ, Egbujor UC, Elmore DW, Etchin SS, Ewan MR, Fedurco M, Fraser L, Fajardo KVF, Furey WS, George D, Gietzen KJ, Goddard CP, Golda GS, Granieri PA, Green DE, Gustafson DL, Hansen NF, Harnish K, Haudenschild CD, Heyer NI, Hims MM, Ho JT, Horgan AM, Hoschler K, Hurwitz S, Ivanov DV, Johnson MQ, James T, Jones TAH, Kang GD, Kerelska TH, Kersey AD, Khrebtukova I, Kindwall AP, Kingsbury Z, Kokko-Gonzales PI, Kumar A, Laurent MA, Lawley CT, Lee SE, Lee X, Liao AK, Loch JA, Lok M, Luo SJ, Mammen RM, Martin JW, McCauley PG, McNitt P, Mehta P, Moon KW, Mullens JW, Newington T, Ning ZM, Ng BL, Novo SM, O'Neill MJ, Osborne MA, Osnowski A, Ostadan O, Paraschos LL, Pickering L, Pike AC, Pike AC, Pinkard DC, Pliskin DP, Podhasky J, Quijano VJ, Raczy C, Rae VH, Rawlings SR, Rodriguez AC, Roe PM, Rogers J, Bacigalupo MCR, Romanov N, Romieu A, Roth RK, Rourke NJ, Ruediger ST, Rusman E, Sanches-Kuiper RM, Schenker MR, Seoane JM, Shaw RJ, Shiver MK, Short SW, Sizto NL, Sluis JP, Smith MA, Sohna JES, Spence EJ, Stevens K, Sutton N, Szajkowski L, Tregidgo CL, Turcatti G, vandeVondele S, Verhovsky Y, Virk SM, Wakelin S, Walcott GC, Wang JW, Worsley GJ, Yan JY, Yau L, Zuerlein M, Rogers J, Mullikin JC, Hurles ME, McCooke NJ, West JS, Oaks FL, Lundberg PL, Klenerman D, Durbin R, Smith AJ: Accurate whole human genome sequencing using reversible terminator chemistry. Nature 2008, 456:53-59.

6. Green RE, Krause J, Ptak SE, Briggs AW, Ronan MT, Simons JF, Du L, Egholm M, Rothberg JM, Paunovic M, Paabo S: Analysis of one million base pairs of Neanderthal DNA. Nature 2006, 444:330-336.

7. Poinar HN, Schwarz C, Qi J, Shapiro B, MacPhee RDE, Buigues B, Tikhonov A, Huson DH, Tomsho LP, Auch A, Rampp M, Miller W, Schuster SC: Metagenomics to paleogenomics: Large-scale sequencing of mammoth DNA. Science 2006, 311:392-394.

8. Zerbino DR, Birney E: Velvet: Algorithms for de novo short read assembly using de Bruijn graphs. Genome Res 2008, 18:821-829.

9. Li RQ, Fan W, Tian G, Zhu HM, He L, Cai J, Huang QF, Cai QL, Li B, Bai YQ, Zhang ZH, Zhang YP, Wang W, Li J, Wei FW, Li H, Jian M, Li JW, Zhang ZL, Nielsen R, Li DW, Gu WJ, Yang ZT, Xuan ZL, Ryder OA, Leung FCC, Zhou Y, Cao JJ, Sun X, Fu YG, Fang XD, Guo XS, Wang B, Hou R, Shen FJ, Mu B, Ni PX, Lin RM, Qian WB, Wang GD, Yu C, Nie WH, Wang JH, Wu ZG, Liang $H Q$, Min JM, Wu Q, Cheng SF, Ruan J, Wang MW, Shi ZB, Wen M, Liu BH, Ren XL, Zheng HS, Dong D, Cook K, Shan G, Zhang H, Kosiol C, Xie XY, Lu ZH, Zheng HC, Li YR, Steiner CC, Lam TTY, Lin SY, Zhang QH, Li GQ, Tian J, Gong TM, Liu HD, Zhang DJ, Fang L, Ye C, Zhang JB, Hu WB, Xu AL, Ren YY, Zhang GJ, Bruford MW, Li QB, Ma LJ, Guo YR, An N, Hu YJ, Zheng Y, Shi YY, Li ZQ, Liu Q, Chen YL, Zhao J, Qu N, Zhao SC, Tian F, Wang XL, Wang HY, XU LZ, Liu X, Vinar T, Wang YJ, Lam TW, Yiu SM, Liu SP, Zhang HM, Li DS, Huang $Y$, Wang $X$, Yang GH, Jiang $Z$, Wang JY, Qin $N$, Li L, Li JX, Bolund L, Kristiansen K, Wong GKS, Olson M, Zhang XQ, Li SG, Yang HM, Wang J, Wang J: The sequence and de novo assembly of the giant panda genome. Nature 2010, 463:311-317.

10. Hillier LW, Miller W, Birney E, Warren W, Hardison RC, Ponting CP, Bork P, Burt DW, Groenen MAM, Delany ME, Dodgson JB, Chinwalla AT, Cliften PF, Clifton SW, Delehaunty KD, Fronick C, Fulton RS, Graves TA, Kremitzki C, 
Layman D, Magrini V, McPherson JD, Miner TL, Minx P, Nash WE, Nhan MN, Nelson JO, Oddy LG, Pohl CS, Randall-Maher J, Smith SM, Wallis JW, Yang SP, Romanov MN, Rondelli CM, Paton B, Smith J, Morrice D, Daniels L, Tempest HG, Robertson L, Masabanda JS, Griffin DK, Vignal A, Fillon V, Jacobbson L, Kerje S, Andersson L, Crooijmans RPM, Aerts J, van der Poel JJ, Ellegren H, Caldwell RB, Hubbard SJ, Grafham DV, Kierzek AM, McLaren SR, Overton IM, Arakawa H, Beattie KJ, Bezzubov Y, Boardman PE, Bonfield JK, Croning MDR, Davies RM, Francis MD, Humphray SJ, Scott CE, Taylor RG, Tickle C, Brown WRA, Rogers J, Buerstedde JM, Wilson SA, Stubbs L, Ovcharenko I, Gordon L, Lucas S, Miller MM, Inoko H, Shiina T, Kaufman J, Salomonsen J, Skjoedt K, Wong GKS, Wang J, Liu B, Wang J, Yu J, Yang HM, Nefedov M, Koriabine M, deJong PJ, Goodstadt L, Webber C, Dickens NJ, Letunic I, Suyama M, Torrents D, von Mering C, Zdobnov EM, Makova K, Nekrutenko A, Elnitski L, Eswara P, King DC, Yang S, Tyekucheva S, Radakrishnan A, Harris RS, Chiaromonte F, Taylor J, He JB, Rijnkels M, Griffiths-Jones S, Ureta-Vidal A, Hoffman MM, Severin J, Searle SMJ, Law AS, Speed D, Waddington D, Cheng Z, Tuzun E, Eichler E, Bao ZR, Flicek P, Shteynberg DD, Brent MR, Bye JM, Huckle EJ, Chatterji S, Dewey C, Pachter L, Kouranov A, Mourelatos Z, Hatzigeorgiou AG, Paterson AH, Ivarie R, Brandstrom M, Axelsson E, Backstrom N, Berlin S, Webster MT, Pourquie O, Reymond A, Ucla C, Antonarakis SE, Long MY, Emerson JJ, Betran E, Dupanloup I, Kaessmann H, Hinrichs AS, Bejerano G, Furey TS, Harte RA, Raney B, Siepel A, Kent WJ, Haussler D, Eyras E, Castelo R, Abril JF, Castellano S, Camara F, Parra G, Guigo R, Bourque G, Tesler G, Pevzner PA, Smit A, Fulton LA, Mardis ER, Wilson RK: Sequence and comparative analysis of the chicken genome provide unique perspectives on vertebrate evolution. Nature 2004, 432:695-716.

11. Axelsson E, Smith NGC, Sundstrom H, Berlin S, Ellegren H: Male-biased mutation rate and divergence in autosomal, Z-linked and W-linked introns of chicken and turkey. Mol Biol Evol 2004, 21:1538-1547.

12. Axelsson E, Webster MT, Smith NGC, Burt DW, Ellegren H: Comparison of the chicken and turkey genomes reveals a higher rate of nucleotide divergence on microchromosomes than macrochromosomes. Genome Res 2005, 15:120-125.

13. Warren WC, Clayton DF, Ellegren H, Arnold AP, Hillier LW, Kunstner A, Searle S, White S, Vilella AJ, Fairley S, Heger A, Kong L, Ponting CP, Jarvis ED, Mello CV, Minx P, Lovell P, Velho TA, Ferris M, Balakrishnan CN, Sinha S, Blatti C, London SE, Li Y, Lin YC, George J, Sweedler J, Southey B, Gunaratne P, Watson M, Nam K, Backstrom N, Smeds L, Nabholz B, Itoh Y, Whitney O, Pfenning AR, Howard J, Volker M, Skinner BM, Griffin DK, Ye L, McLaren WM, Flicek P, Quesada V, Velasco G, Lopez-Otin C, Puente XS, Olender T, Lancet D, Smit AF, Hubley R, Konkel MK, Walker JA, Batzer MA, Gu W, Pollock DD, Chen L, Cheng Z, Eichler EE, Stapley J, Slate J, Ekblom R, Birkhead T, Burke T, Burt D, Scharff C, Adam I, Richard H, Sultan M, Soldatov A, Lehrach H, Edwards SV, Yang SP, Li X, Graves T, Fulton L, Nelson J, Chinwalla A, Hou S, Mardis ER, Wilson RK: The genome of a songbird. Nature 2010, 464:757-762.

14. Axelsson E, Ellegren $\mathrm{H}$ : Quantification of Adaptive Evolution of Genes Expressed in Avian Brain and the Population Size Effect on the Efficacy of Selection. Mol Biol Evol 2009, 26:1073-1079.

15. Axelsson E, Hultin-Rosenberg L, Brandstrom M, Zwahlen M, Clayton DF, Ellegren $\mathrm{H}$ : Natural selection in avian protein-coding genes expressed in brain. Mol Ecol 2008, 17:3008-3017.

16. Ekblom R, Balakrishnan CN, Burke T, Slate J: Digital gene expression analysis of the zebra finch genome. BMC Genomics 2010, 11:219.

17. Nam K, Mugal C, Nabholz B, Schielzeth H, Wolf JB, Backstrom N, Kunstner A, Balakrishnan CN, Heger A, Ponting CP, Clayton DF, Ellegren H: Molecular evolution of genes in avian genomes. Genome Biol 2010, 11:R68.

18. Barker MS, Dlugosch KM, Reddy ACC, Amyotte SN, Rieseberg LH: SCARF: maximizing next-generation EST assemblies for evolutionary and population genomic analyses. Bioinformatics 2009, 25:535-536.

19. Kunstner A, Wolf JBW, Backstrom N, Whitney O, Balakrishnan CN, Day L, Edwards SV, Janes DE, Schlinger BA, Wilson RK, Jarvis ED, Warren WC, Ellegren $\mathrm{H}$ : Comparative genomics based on massive parallel transcriptome sequencing reveals patterns of substitution and selection across 10 bird species. Mol Ecol 2010, 19:266-276.

20. Kumar S, Hedges SB: A molecular timescale for vertebrate evolution. Nature 1998, 392:917-920.

21. Brown JW, Rest JS, Garcia-Moreno J, Sorenson MD, Mindell DP: Strong mitochondrial DNA support for a Cretaceous origin of modern avian lineages. BMC Biol 2008, 6:6.
22. Pereira SL, Baker AJ: A mitogenomic timescale for birds detects variable phylogenetic rates of molecular evolution and refutes the standard molecular clock. Mol Biol Evol 2006, 23:1731-1740.

23. Benton MJ, Donoghue PC: Paleontological evidence to date the tree of life. Mol Biol Evol 2007, 24:26-53.

24. Pal C, Papp B, Hurst LD: Highly expressed genes in yeast evolve slowly. Genetics 2001, 158:927-931.

25. Subramanian S, Kumar S: Gene expression intensity shapes evolutionary rates of the proteins encoded by the vertebrate genome. Genetics 2004 168:373-381.

26. Subramanian S: Nearly neutrality and the evolution of codon usage bias in eukaryotic genomes. Genetics 2008, 178:2429-2432.

27. Reisz RR, Muller J: Molecular timescales and the fossil record: a paleontological perspective. Trends Genet 2004, 20:237-241.

28. Benton MJ: The fossil record2. London: Chapman and Hall, London; 1993.

29. Thorne JL: MULIDISTRIBUTE 2003 [http://statgen.ncsu.edu/thorne/ multidivtime.html].

30. Duret L, Mouchiroud D, Gouy M: Hovergen - a Database of Homologous Vertebrate Genes. Nucleic Acids Res 1994, 22:2360-2365.

31. Yang ZH: PAML 4: Phylogenetic analysis by maximum likelihood. Mol Biol Evol 2007, 24:1586-1591.

32. Altschul SF, Madden TL, Schaffer AA, Zhang JH, Zhang Z, Miller W, Lipman DJ: Gapped BLAST and PSI-BLAST: a new generation of protein database search programs. Nucleic Acids Res 1997, 25:3389-3402.

33. Larkin MA, Blackshields G, Brown NP, Chenna R, McGettigan PA, McWilliam H, Valentin F, Wallace IM, Wilm A, Lopez R, Thompson JD, Gibson TJ, Higgins DG: Clustal W and clustal X version 2.0. Bioinformatics 2007, 23:2947-2948.

34. Thorne $\mathrm{J}$, Kishino $\mathrm{H}$ : Divergence time and evolutionary rate estimation with multilocus data. Syst Biol 2002, 51:689-702.

35. Drummond AJ, Rambaut A: BEAST: Bayesian evolutionary analysis by sampling trees. BMC Evol Biol 2007, 7:214.

\section{doi:10.1186/1471-2148-10-387}

Cite this article as: Subramanian et al:: Next generation sequencing and analysis of a conserved transcriptome of New Zealand's kiwi. BMC Evolutionary Biology 2010 10:387.

\section{Submit your next manuscript to BioMed Central and take full advantage of:}

- Convenient online submission

- Thorough peer review

- No space constraints or color figure charges

- Immediate publication on acceptance

- Inclusion in PubMed, CAS, Scopus and Google Scholar

- Research which is freely available for redistribution

Submit your manuscript at www.biomedcentral.com/submit
C Biomed Central 